\title{
The Effects of North America Free Trade Agreement on Mexican Environmental Policy (1994-2004)
}

\author{
Ningu, Julius Kenneth, Jorge Torres Jácome, SoniaEmilia Silva Gomez and Ricardo Pérez Áviles
}

\begin{abstract}
The scope of this study was to analyze the implementation of the environmental policy and the way Mexico has integrated the environmental aspects into a North America Free Trade Agreement (NAFTA). We are aware of the fact that many environmental costs do not necessarily reflect the environmental damage. Environmental costs are often defined by determining either the willingness of the users to pay for the damages or for admittance of claims for damage. Since everyone has the right to a clean and thriving natural environment it is the policy maker who determines the basis of admittance of the most correct means to determine environmental costs in order to reduce the damages. Methodologically, we analyzed the existence and implementation of environmental policy. Instead of looking at the tradeoff between trade related incentives and environmental considerations, we analyzed how trade-offs changes under free trade effects the policy issues. When compared the countries environmental policy and the NAFTA stipulations we found that Mexico has a well-defined environmental policy but less integrated in the free trade agreement. The decision makers have increased the concessions of consumption of fixed capital as a means to increase gains from trade. This has lead to increased environmental damage, natural resource depletion and environmental costs.
\end{abstract}

Key words: Free trade, environmental policy, pollution and the related costs

\section{INTRODUCTION}

In Mexico, environmentalists and the public in general consider NAFTA as a threat to an adequate implementation of environmental policy. It is urged that NAFTA has influenced the relaxation of environmental standards in order to gain a competitive edge of Mexico over her trading partners. In the context of free trade, strategic environmental policies differ from efficient policies when trade related incentives are used. For example, a less restrictive environmental policy makes importers to be aggressive competitors in the markets thus, increasing the rate of exploitation of natural resources ${ }^{[1]}$.

The experience shows that tax and tariffs reduction implies higher marginal damage to the environment for lack of revenue to cover the depletion-related costs ${ }^{[2]}$. Once used as a strategy to gain a competitive edge among trading partners, it ruins the government power to use environmental policies effectively. Changes in trade pattern (in terms of increase or decrease of imports and exports) are determined by the market forces.

Every environmental challenge has technological, economical and a political aspect, which must be understood, addressed and solved. Without a certain insight into these factors and their interrelationships, it can lead to inaccurate conclusions and thereby make the wrong decisions. To succeed in solving the environmental problems, a decision making factor is crucial in order to avoid costly detours and dead ends. The desire to reduce environmental problems is a political will, while gaining from trade has to do with market forces backed by well designed trade policies. Strict environmental measures can help to reduce environmental damage.

\section{MATERIALS AND METHODS}

They analyzed the international conventions (World Trade Organization (WTO)) and the country's environmental policy on aspects pertaining to trade. The national environmental policies were analyzed in order to compare the strategies used in their (environmental policy) implementation under NAFTA. The sources of information and data included: the NAFTA document ${ }^{[3]}$ on the compliance with the country's environmental policy, the Instituto Nacional de Estadística Geografía e Informática (INEGI) on Systems for Economic and Ecological Accounts as it incorporates economic aggregates and adjusted derivatives of changes to natural resources and the environment ${ }^{[4]}$.

Other sources included: Ley General de Equilibrio Ecológico y Protección al Ambiental (LGEEPA), Secretaría de Medio Ambiente y Recursos Naturales (SEMARNAT), the National Political Constitution, the National Law of Planning, the National Plan for Development (2001 - 2006), the national environmental norms developed by Instituto Nacional de Ecología (INE). They analyzed environmental policy in terms of

Corresponding Author: Ningu, Julius Kenneth, (Posgrado en Ciencias Ambientales, Instituto de Ciencias, Benemérita Universidad Autónoma de Puebla; 14 Sur 6301, Colonia: San Manuel Tel/Fax (+52)-222-229-5500 ext. 7353 
resource use control which involves assigning, managing and optimizing its use in the national development plans.

The costs of consumption of capital include the depletion of oil reserves, water, deforestation and other natural resources; all together they constitute a quantitative effect of NAFTA. In literature, there are different factors considered to be responsible for environmental damage such as demographic factors, poverty, inequity, public policies, economic policies, the market, social changes and development ${ }^{[5]}$. However; in each case it is necessary to analyze every factor and its effects. This is not an easy task due to time and space between the factor and its effects, it sometimes owes difficult to identify and measure their effects. Cost method on environmental damage, refers to the adjustments of the Gross. National Product (GNP) on the changes of the net accumulation of economic assets that includes the net accumulation of environmental assets ${ }^{[6]}$ and other resource use.

The variable of costs on environmental damage and its protection was considered from the point of view of decision-making process. The aspects of control and cost on environmental damage were used in tracking and analyzing the reasons of resource allocation as well as in application of appropriate measures. The variables under consideration included the consumption of fixed capital (in economic terms represents the amount of fixed assets used up, during the period under consideration, as a result of normal wear and tear and foreseeable obsolescence, including a provision for losses of fixed assets as a result of accidental damage which can be insured against), costs of depletion and degradation of natural resources and, costs of environmental protection.

\section{RESULTS AND DISCUSSION}

In 1992 the Rio de Janeiro convention under Agenda 21 Principle 4 declared that sustainable development, environmental protection cannot be considered in isolation $^{[7]}$. Moreover; the World Trade Organization (WTO) Appellant Body declared that, members are free to adopt their own policies aimed at protecting the environment as long as, in so doing, they fulfil their obligations and respect the rights of other members. In case of Mexico, it was found that in the National Political Constitution under Articles 25 and 26 these concepts are well defined and applied in national development plans since her independence, and Mexico has acted and reacted positively to protect and defend her resources, wrights and national policies ${ }^{[8]}$.

It was further found that, the concept of sustainable development is well stipulated in Ley General de Equilibrio Ecológico y Protección al Ambiental (1996) under Article 3 fraction xi, and defines sustainable development in terms of environmental, economical and social sustainability. The law declares the existence of sustainability which can be evaluated through indicators. It concludes; sustainability can only be interpreted in terms of improved living standards of the people, adequate ecological and environmental protection $^{[9]}$. Under the same Law section III, it stipulates on the investors being responsible for the pollution generated by their activities.

Further more; Article 109 (introduced in 1996) obliges the SEMARNAT (Secretaría de Medio Ambiente y Recursos Naturales) as a responsible government organ to monitor environmental pollution. In the National Law of Planning under article 12 declares the importance of integrating environmental aspects in various sectors as a central element in the development of the country. In the National Plan for Development (2001 - 2006) under objective 5, it stresses on the integration of environmental considerations into policies and decision-making processes as a prerequisite for achieving sustainable development.

We found that there are 62 environmental norms developed by the Instituto Nacional de Ecología and published in the Diario Oficial de la Federación between October 1993 and May 1994. The norms are grouped under five categories: for control of residual water, atmospheric pollution, monitoring of air pollution, toxic wastes production and natural resources degradation. Although NAFTA is not an environmental agreement, it was found that, under Article 114 (1 \& 2), stipulates that each country must develop and apply its own environmental laws to ensure environmental and the public health protection. It further stipulates that, it is improper to eliminate or weaken environmental norms for commercial purpose.

They found that immediately after signing the agreement, most of the imported products under NAFTA became tax free. According to the tax and tariffs reduction, it was found that $70 \%$ of the imports became tax free by $1^{\text {st }}$ of January $1994^{[10]}$. The taxes and tariffs for the rest of the products were reduced gradually such that by 1998 , more than $15 \%$ of her imports were tax free ${ }^{[11]}$. It was expected by $1^{\text {st }}$ of January 2003, 99\% of her imports under NAFTA would become tax-free. From January 2003, the tax and tariffs reduction process continued and will end up in 2008 for some products such as canned fish and juice of some fruits. This process catapulted the aggressiveness of NAFTA member countries and the trading firms to take advantage of these incentives in gaining the competitive edge in the internal as well as in the external markets. As a result there was an increase in the consumption of fixed capital with consequences of environmental degradation.

In the Mexican development perspective, the results of NAFTA are expensive. INEGI considers the financial cost of the environmental degradation between 1989 and 2003 as more than $10 \%$ of the GNP, with an annual average rate of 36 billion dollars in damages (47 
million dollars only in 1999). This cost is not opposed to the productive growth, which had an annual average rate of $2.5 \%$ or 14 billion dollars per year. It is true that there is an environmental damage in Mexico, but not on an account that it is a paradise of pollution. What generates higher environmental costs, are: a continued exploitation of natural resources in the production process and lack of appropriate mechanisms to administer the economic growth. As a result, environmental degradation increases at the expense of other sectors such as social and economic sectors. It was found that the environmental degradation represented an average of $10.5 \%$ of the GNP at the current prices in the period under analysis.

Diario Oficial (Lunes 20 de Diciembre de 1993) 10 C $\mathrm{C}^{[10]}$

Estrategia económica ${ }^{[11]}$, La desgravación arancelaria en 2003 en el marco del TLCAN. Also available on line at: http://www.todito.com/paginas/eventos/entrevista/desgr avacion.html. Revised on $27^{\text {th }}$ March 2005.

It was also found that, some few years before NAFTA, Mexico had an industrial monitoring program on pollution. But shortly after signing the Agreement the country entered in an economic crisis at the end of 1994, and as part of recovery process she relaxed the environmental policy. According to INEGI, between 1994 and 2004 the real cost on environmental protection lowered by almost $45 \%$. This amount is approximately 200 million dollars. Under the same period the allocations used to atmospheric protection as percentage of the GNP, lowered in comparison to other OECD countries ${ }^{[12]}$. This amount accounted only one fifth of the others member countries.

In 2002 the costs of environmental degradation and natural resources depletion amounted to 65,934 million dollars, and this constituted a $10.0 \%$ of the GNP and the expenses made in the same year for protection and reduction of environmental damage generated by production activities reached an amount of 3,473 million dollars: This amount represented only $5.3 \%$ of the cost of depletion. The higher costs were generated by air pollution (industrial pollution and emissions from vehicles) with $79.5 \%$; followed by the costs related to the reduction of oil reserves and pollution of water reserves by residual discharges with $5.9 \%$ each. Soil pollution by solid wastes had $3.9 \%$ and those generated by deforestation for timber products constituted a $2.4 \%$. Soil erosion constituted $1.7 \%$ and the costs generated by overexploitation of subterranean water was $0.7 \%$.

European Environmental Agency and OECD ${ }^{[12]}$. Database on instruments used for environmental policy and natural resources management. Also available on line

http://www2.oecd.org/ecoinst/queries/index.htm.

Revised on $28^{\text {th }}$ March 2005.

The environmental damage (by extraction of petroleum, underground water and forests products, soil erosion, air, and water pollution) represented an average of $11.5 \%$ of the GNP at the current prices in period of 11 years (1994-2004). This percentage represents a pollution jointly generated by Agricultural sector, crude oil and natural gas extraction, pharmaceutical products, hydraulic cement, basic iron and steel industries, machinery and non- electrical equipment, electronic devices, vehicles and communications sectors.

It was found that, recently Mexico has improved her performance in some economic and social aspects such as Gross National income, unemployment, poverty and income per capita but had a deteriorated performance on environmental as well as on policy aspects. From the political point of view, the Mexican development strategies have given priority to some sectors. This impairs the objective of the nation in achieving the development goal. The reduction of environmental damages is possible to achieve and depends on which alternatives are currently used under which policy and technological endowments. Therefore, the current development policies and strategies have great influence on how the damages can be reduced or eliminated.

Acceptable environmental standards can only be achieved when NAFTA member countries are aware of the consequences of their activities on the environmental. The objective of stern measures on environmental is to encourage the agents in the market to change their behavior in an environmentally positive direction. They reflect on how great a pressure must be put on those involved before they react, and not the actual cost of implementing the necessary methods, which actually lead to less environmental damage.

If decision-makers can incorporate environmental aspects on policy, it can save the country's valuable resources and the nation's future natural resources simultaneously protecting the environment. However, if the costs of environmental damage remains unknown and are not unaccounted for in the decision-making process, environmental management and investments cannot be made adequately. The current decisionmaking processes do not consider environmental costs and hinders their optimal use. Evaluating the extent to which existing decision-making process include environmental aspects is an important task towards incorporating environmental costs and considerations into resource use and allocation. Conducting this evaluation and making the information available to the public is the primary objective.

\section{CONCLUSION}

The analysis found that the environmental policy and regulations are less effective because the trade policy of using incentives as means to gain the margin of competitiveness. This has given raise to an increased environmental damage and an accelerated depletion of 
natural resources. It was also considered that, not every environmental damage can be measured in a purely monetary terms. The goal, in other words, is to create only increase in value with no negative impact.

Ideally, the environmental policies should act on the basis of the levels of the actual environmental damages and resource depletion. Environmental taxes do not totally eliminate the damages to the environment and natural resource depletion. While environmental damage and natural resource depletion is increasing the decisions makers are hesitant to carry out the steps necessary to reverse the situation. Definitely, it is not a lack of environmental damage and natural resource depletion, but neither is there an abundance of simple, rational solutions available. With this in mind, any new source of pollution is undesirable and few known solutions should not be left unimplemented. This means, environmental costs are infinite, in other words, every bit of discharge, which causes environmental impact, should be avoided. It is false to assume that as soon as Mexico applies its environmental policies correctly under NAFTA there will be no further environmental damages and natural resource depletion, this is due to the fact that even the international standards are not ambitious enough compared to the challenges the world faces in dealing with environmental damage and natural resource depletion degradation. Therefore; there is a need for even greater efforts from the international community to ensure that the damage and resource depletion is reduced.

\section{REFERENCES}

1. Barrett, S., 1994. Strategic environmental policy and international trade. J. Public Econ., 54: 325-338.

2. Diario Oficial (Lunes 20 de Diciembre de 1993) 10 C C.

3. Estrategia Económica, 2002. La desgravación arancelaria en 2003 en el marco del TLCAN. http://www.todito.com/paginas/eventos/entrevista/ desgravacion.html. Revised on $27^{\text {th }}$ March 2005.

4. European Environmental Agency and OECD, 2004. Database on instruments used for environmental policy and natural resources management.

http://www2.oecd.org/ecoinst/queries/index.htm. Revised on $28^{\text {th }}$ March 2005.
5. Foreign Trade Information System (FTIS), 1996. http://www.sice.oas.org/Trade/

nafta_s/CAP03_1.asp\#A302. Revised $2^{\text {nd }}$ April 2005.

6. Kennedy, P.W., 1994. Equilibrium Pollution Taxes in Open Economies with Imperfect Competition. In: E. van Ireland (Ed.), International Environmental Economics: Theories, Models and Application to climatic change, International Trade and Acidification, Elsevier, Amsterdam, pp: 195212.

7. Krutilla, J., 1991. Environmental regulations in an open economy. J. Environ. Manag., 20: 127-135 and J.R. Markusen, 1975. International externalities and optimal tax structures. J. Intl. Econ., 5: 15-29.

8. Ley General de Equilibrio Ecolgico y Proteccin ambiental (LGEEPA) (1996). Artculo 3 fracc. xi.

9. Marceau, G., 2002. The precautionary principle under WTO law. Precaution from Rio to Johannesburg. Proc. Geneva Environment Network Roundtable. Suisse EPA.

10. Office of NAFTA and Inter-American Affairs, 2005. International Trade Administration. Market Access and Compliance. http://www.mac.doc.gov/nafta/naftatext.html . Revised on $2^{\text {nd }}$ April 2005.

11. Owens, J., 2004. Are the current treaty rules for taxing business profits appropriate for ecommerce? pp: 30-67. Head, Centre for Tax Policy and Administration OECD 2, rue André Pascal 75775 Paris FRANCE.

12. Rio, 1992. http://www.unep.org/Documents/Default.asp?Docu mentID $=78 \&$ ArticleID $=1163$. Revised on $25^{\text {th }}$ October 2005.

13. Trade Area of the Americas (FTAA), 2003. Official Website of the Free Trade Area of Americas. http://www.ftaa-alca.org/alca_e.asp. Revised on $4^{\text {th }}$ May 2005.

14. World Commission, 1987, pp: 10 and 62. 